\section{Technology: International Dimensions}

\section{James J. F. Forest}

James J. F. Forest is director of strategic analysis at Franklin Pierce College and a technology consultant for higher education and nonprofit organizations. Address: College Road, Box 60, Rindge, NH 03461 . Email: <Forest@higher-ed.org>.

$\mathrm{T}$ he use of technology in higher education continues to expand rapidly and globally, offering new approaches to classroom teaching and learning as well as new ways for academics to connect with one another over long distances. Not long ago, international colleagues would see each other at the occasional conference, write letters, or rack up sizable long-distance phone bills. Today the Internet allows inexpensive, daily interaction between colleagues around the world. It is useful to take an occasional snapshot of the opportunities and challenges presented by these new technologies and their impact on academic life and work.

\section{International Collaboration}

Putting together an international collection of essays has never been easier. Book chapters can be solicited, reviewed, edited, designed, and printed as camera-ready copy for the publisher-all using a standard desktop computer with an Internet connection and a laser printer. The submission and review of proposals for academic conferences can be conducted entirely over the World Wide Web or by sending files as e-mail enclosures. Traditional forms of research collaboration-printing, mailing, and waiting for a response-are being replaced by faster, more efficient means of communication on a global scale. Listserv e-mail discussion groups make possible the international sharing of research questions and findings, sometimes leading to research partnerships between academics who discover their shared interests on-line.

\section{A New Cadre of Publishers}

With a cheap desktop PC, an Internet connection, and a web-hosting service, anyone can now be a provider of information to the masses at amazingly low cost. By developing and maintaining your own website, you can "publish" everything from scholarly essays and research agendas to pictures of your family and more. No more page limits, margin or font sizes to worry about. All you need is something to say, a few website development tools, and an imaginative way of presenting your information on the Internet. New web-based newsletters and journals are cropping up throughout academe every month, as faculty worldwide learn to make use of this mode of publishing their work.
Much like the introduction of the printing press years ago, the impact of the Internet on information distribution has been enormous.

\section{Access to Information Worldwide}

More websites means more information at our fingertips. In the United States, students are turning increasingly to the web as a primary source of information previously only obtainable at their school library. The same information available to students in the United States is available to Internet-connected students and scholars in other countries as well. A host of on-line translators are even available to convert English-language websites into the language of choice. Of particular interest, college and university libraries worldwide are offering an increasing amount of information over the web. Students at a small rural college with a poorly stocked library can now find virtually any reference resource they need through the web. Information clearinghouses-like ERIC — and specific research databases for disciplines in the sciences or humanities offer a vast array of research opportunities for anyone with an adequate connection to the Internet.

\section{Gathering Research Data}

With the development and proper use of web-based surveys, a researcher can collect data from an international population of subjects. For example, imagine a survey of the academic profession in 14 geographically diverse countries. Using your website, you can provide an on-line survey form to the faculty in these countries that they fill out and submit directly into your database. No more mailing costs, or data entry hassles, and the timespan involved in your research project has been reduced dramatically.

Much like the introduction of the printing press years ago, the impact of the Internet on information distribution has been enormous.

\section{International Teaching and Learning Tools}

Several free on-line services provide course website development and hosting for faculty in all disciplines throughout the world. Faculty can offer on the web their course syllabi, calendar of assignments and meetings, supplemental readings, and other documents traditionally photocopied and distributed in class. More importantly, the service also offers interactive features, allowing faculty and students to create discussion forums on the Internet in which they and fellow scholars and learners around the world can 
engage in problem solving. This on-line interaction is effective for drawing out those students who usually do not speak up in class. Through hyperlinks, an on-line course website can also direct students to useful sources of information on the web.

\section{Challenges}

Despite the ways in which it adds an exciting new international dimension to academic life and work, technology also presents several challenges and responsibilities. Faculty are now faced with issues of information legitimacy and quality. After spending the previous evening surfing the web, a student may come to class and declare with absolute certainty that the Holocaust could never have happened. How does the teacher deal with this situation and its impact on other students' perceptions? For educators, this presents the new task of teaching students how to judge information sources and to seek multiple perspectives on issues before deciding for themselves what is fact and what is fantasy.

The new technologies also have other implications for the college teacher seeking new and inventive ways to encourage students to develop their thinking and analytic skills. Faculty also have to evaluate themselves and their colleagues in terms of the quality of information offered on-line within their disciplines. Rather than viewing the web as a potential "soap box," faculty could better serve the learning community by linking their websites to those of colleagues so that potential browsers might compare and contrast their differing arguments.

Increased access to information has also led to challenges in how we address issues of knowledge reproduction, copyright, distribution of research findings, and rewards for creativity. From "fair use" policies to institutional codes of conduct, the higher education community worldwide is grappling with a host of issues related to how we conduct ourselves on-line. Nevertheless, the impact of technology on academic life and work has been mostly positive. Each of us bears our own responsibility for ensuring the integrity of information transmitted through our computers-just as we take so seriously our responsibilities in ensuring the integrity of the information we provide each other in print. Our institutions of higher education have a clear mandate to provide training and professional development for faculty to make effective use of new technologies in research and teaching. How we respond to the challenges and opportunities of new technologies will have a considerable effect on the course of higher education in the next decade.

The following are some recommended websites:

International Higher Education: <http://www.bc.edu/cihe> and $<$ http://www.higher-ed.org>; Web Page Language Translators: $<$ http://babelfish.altavista.com> and <http://translator.go.com>; Classroom Teaching \& Learning Tools: <http://www.blackboard.com> and $<$ http://bestpractice.net $>$.

\section{Internationalizing French Higher Education}

\author{
Hoa Tran \\ Hoa Tran is a consultant on higher education who works with UNESCO \\ and other agencies. Address: 11 rue du Belvedere, 56400 Auray, France.
}

A $t$ first glance, French universities give some semblance of looking beyond national borders, with their involvement in short-term exchanges of students and faculty. Every year the University of South Brittany, for example, sends approximately 20 students abroad for three to six months. As for faculty, 4 to 8 go abroad per year, for about two weeks. French universities receive roughly the same number of foreign students and faculty from their European partners. A closer look, however, reveals the limited nature of these international activities. Moreover, funding comes from the European Union's Socrates-ERASMUS program, and they are strictly intra-Europe. Apart from recent contacts with universities in Francophone Canada and Africa, little progress has been made in collaborating with universities outside the European Union. French universities do see exposure to the international environment as beneficial, but more for cultural discovery than for academic benefit. Only in political studies, foreign languages and business management does one find some predisposition toward internationalization.

A similar lack of enthusiasm is found with regard to receiving foreign students for full-degree programs. French universities lack the rich mix of students from different countries one sees on American campuses. Most of the "foreign" students have actually grown up in France, and only a handful are recipients of scholarships. While American universities have highly developed structures to receive and manage hundreds of thousand foreign students, most French universities set up "international relations" sections in the last few years.

Faculty may attend international conferences, or spend few weeks at a foreign (partner) university, teaching (in French) what they teach at home. Foreign exchange professors come to France for similarly short periods. This is international collaboration on a superficial level - an indication that international education is not a priority on the agenda. Nevertheless, French academics, functioning in a highly regulated bureaucracy, are captivated by the freedom of American academia, as well as the American approach toward teaching and research. But this curiosity has not yet been translated into programs of international collaboration. Although French academics are interested in links with universities in Latin America and Asia, they are motivated more by a desire for tourism or cultural enrichment than for true academic exchange. 